\title{
Incompatible Crossmatch with Bombay Phenotype (Oh) - A Case Report
} Huda $\mathrm{KM}^{1}$, Kibria $\mathrm{OFG}^{2}$

\section{Abstract}

Blood serology plays a vital role in transfusion medicine. Presence of an irregular antibody (anti H) in the plasma reacting with all the red cells exhibiting the normal red cell $\mathrm{ABO}$ phenotype, the $\mathrm{h} / \mathrm{h}$ (Bombay) phenotype. The $\mathrm{h} / \mathrm{h}$ phenotype also known as $\mathrm{Oh}$ or Bombay blood group is a rare blood type. It was first discovered in Bombay (Mumbai) in India by Dr.Y.G. Bhende et al in 1952. ${ }^{1}$ Generally present in about 4 per million of the human population, though in some places such as Mumbai (Bombay) locals can have occurrences in as much as 1 in 10,000 of inhabitants. ${ }^{2}$ It is also very rare in Bangladesh. The first case was reported in 1990 where three sisters in a same family were of 'Bombay' phenotype ${ }^{3}$.

A 28-year-old male of Noakhali district was admitted to Apollo Hospitals Dhaka on 21st may 2016 with road traffic accident with pelvic fracture. His $\mathrm{ABO}$ and $\mathrm{Rh}$ blood group was detected as $\mathrm{O}$ positive by usual blood grouping test procedure. But his cross match was incompatible with several $O$ positive blood units. Though the patient's blood group phenotype initially mimic normal group $O$ type by usual test procedure but became apparent when his serum was tested against group $\mathrm{O}$ red cells and strong immediate spin agglutination developed at a thermal range $4^{\circ}$ to $37^{\circ} \mathrm{C}$. After testing with anti $\mathrm{H}$ Lectin, Ulex europaeus having anti $\mathrm{H}$ like activity, it was detected as Bombay blood group. Therefore, proper serum grouping using A cell, B cell and $\mathrm{O}$ cell is necessary to detect this group. Bombay phenotype individual do not express $\mathrm{H}, \mathrm{A}$ and $\mathrm{B}$ antigen on their red cells and secretions but their plasma contains potent anti $\mathrm{H}$, anti $\mathrm{A}$ and anti $\mathrm{B}$ due to lack $\mathrm{H}$ antigen. ${ }^{4}$ Normal $\mathrm{O}$ group red cells does not have $\mathrm{A}$ or $\mathrm{B}$ antigen but their membrane expresses abundant $\mathrm{H}$ antigen. Anti $\mathrm{H}$ of Bombay phenotype serum gives incompatible cross match with all red blood cells of normal $\mathrm{ABO}$ phenotype containing $\mathrm{H}$ antigen. $\mathrm{Oh}$ phenotype person can receive only autologous blood or blood from another Bombay blood group donor. ${ }^{5}$ This patient has received blood from her own sister who was also Bombay phenotype but his other four brothers were normal $\mathrm{O}$ group. Later on he was transfused with blood from Bombay blood group donor, arranged from "Think Foundation", Mumbai, India for his orthopedic surgery. Both forward and reverse grouping is important for safe transfusion. If not followed, it may lead to people with Bombay blood group, not being detected and categorized as $\mathrm{O}$ group. Therefore, proper reverse grouping is necessary to detect this group and cross matching at different thermal range also plays a vital role in transfusion safety.

\section{Key words}

Bombay blood group, forward and reverse grouping, Incompatible cross match, autologous blood transfusion. 


\section{Introduction}

The Bombay phenotype and Para-Bombay phenotypes are very rare blood group worldwide. In India, where $\mathrm{H}$ deficiency was first discovered $^{6}$, the frequency of both phenotypes combined is 1 in 10,000 individuals $^{7}$ except among the tribal population of Orissa where the incidence has been reported as 1 in $76000^{8}$ Incidence is higher in some states of India where the consanguinity is a common practice. ${ }^{9}$ It occurs 1 per 1,000,000 individuals in Europe ${ }^{7}$ and 1:1000 were found in a small French Reunion island in the Indian Ocean. ${ }^{7,9}$ The homozygous $\mathrm{H}$ deficiency is slightly more common in Taiwan, affecting 1 of 8,000 people. ${ }^{7,10}$ Both the classical Bombay phenotype and a partial $\mathrm{H}$ deficiency were seen among the islanders. ${ }^{2}$

$\mathrm{H}$ deficient Bombay phenotype is also very rare in Bangladesh. The first case was reported in 1990 where three sisters in a same family known as Miah family were of 'Bombay' phenotype. ${ }^{3}$ Another case was reported in 2010 who was a 35 years old lady, a diagnosed case of carcinoma of pancreas with Whipple's operation performed six months back and was on chemotherapy. ${ }^{8}$ Afterwards a few cases have been reported incidentally due to transfusion reaction or incompatible cross match of the hospital cases needed blood transfusion but the prevalence of Bombay phenotype among the general population in Bangladesh is not yet known.

Bombay phenotype $(\mathrm{Oh})$ results from the inheritance of two rare recessive $h$ genes at a locus other than the $\mathrm{ABO}$ gene locus ${ }^{10}$ and is the result of the mutation of $\mathrm{H}$ gene(FUT1) that express the $\mathrm{H}$ antigen on the red cells of $\mathrm{ABO}$ blood group and FUT2 gene indirectly encodes a soluble form of the $\mathrm{H}$ antigen found in saliva and other body fluids. ${ }^{8}$ So $\mathrm{H}$ antigen is not expressed on RBCs and not present in saliva of a Bombay phenotype individual. Serum contains anti-H and it is commonly IgM which activate the complement cascade and lyses RBCs in the circulation (intravascular hemolysis). Mothers with the Bombay phenotype $(\mathrm{Oh}, \mathrm{h} / \mathrm{h})$ can develop $\mathrm{HDN}$. Genotype is usually $\mathrm{h} / \mathrm{h}$ se/se. ${ }^{2}$ In Para-Bombay phenotype ( $\mathrm{Ah}$ and $\mathrm{Bh}$ ) $\mathrm{H}$ antigen is weakly expressed on RBCs. $H$ antigen may be present or absent in saliva but Serum contains anti-H. Genotype: (H), Se/Se or Se/se or se/se $\mathrm{se}^{2}$. Mostly all $\mathrm{Oh}$ people are $\mathrm{Le}(\mathrm{a}+\mathrm{b}-)$ and are non-secretors of A, B and $\mathrm{H}$ antigens. ${ }^{3}$ In all populations $99.9 \%$ of RBCs express $\mathrm{H}$ antigen. ${ }^{6} \mathrm{H}$ antigen is synthesized by $\mathrm{H}$ gene (FUT1) and (FUT2) which is located on chromosome 19 and give rise to glycosyltransferase that add 1-fucose to a precursor substance to produce $\mathrm{H}$ antigen on red cells. ${ }^{10}$ Depending upon a person's ABO blood type, the $\mathrm{H}$ antigen is converted into either the $\mathrm{A}$ antigen or B antigen, or both. If a person has blood group $\mathrm{O}$, the $\mathrm{H}$ antigen remains unmodified. Therefore, the $\mathrm{H}$ antigen is present in the highest amounts in blood type $\mathrm{O}$ and in the least amounts in blood type $\mathrm{AB}$. If $\mathrm{H}$ antigen is not produced, the $\mathrm{ABO}$ blood group antigens are also not produced. So the frequency of the $\mathrm{H}$ antigen is equivalent to the frequency of blood group $O$.

hh phenotype patient can be transfused only with RBCs that also lacks the $\mathrm{H}, \mathrm{A}$, and $\mathrm{B}$ antigens i.e. they can either receive autologous donation or blood from an individual of Bombay phenotype only; no other blood will match in case of an emergency blood transfusion. 9,5 


\section{Case report}

A 28-year-old male of Noakhali district was admitted to Apollo Hospitals Dhaka on 21st may 2016 with road traffic accident with pelvic fracture. His $\mathrm{ABO}$ and $\mathrm{Rh}$ blood group was detected as $O$ positive by applying the standard forward and reverse grouping column agglutination technology (gel card) where only A cell and B cell was used for reverse grouping. $O$ control cell was not used in reverse blood grouping. But a strong 4+ reaction was observed in the major cross matching by usual column agglutination technology (gel card). later on after using the $O$ control cell in reverse grouping, we have found a discrepancy between forward and reverse grouping. Forward grouping shows as $O$ positive and in reverse we have noted an unusual strong 4+ reaction with $O$ cells at a thermal range of 4 to $37^{\circ} \mathrm{C}$ which is usually common for $\mathrm{Oh}$ phenotype. Simultaneously both major and minor cross matching was done using a tube technique. We have noticed a strong 4+ reaction in the major cross matching and minor cross matching was compatible. The antibody screening was done and the results of antibody screening showed strong agglutination in all 3 panel cells at a wide thermal range and auto control was negative. So, the patient's red cells were tested against anti $-\mathrm{H}$ lectin, showed the absence of $\mathbf{H}$ antigen. This confirms $\mathrm{O}$ Bombay. We did $\mathrm{ABO}$ grouping for other family members. Four of his brothers were $\mathrm{O}$ positive ( $\mathrm{OH}$ phenotype) and cross matching was incompatible with them but his sister was found $\mathrm{Oh}$ phenotype and was compatible with the patients' blood. So he was transfused with his sisters Bombay blood. So Bombay phenotype should be transfused only with Bombay pheno- type. The patient has also given history of his maternal aunt was diagnosed as $\mathrm{O}$ positive but died immediately after blood transfusion. Transfusing $\mathrm{O}$ group blood would lead to acute transfusion reaction since all anti $\mathrm{H}$ immunoglobulin can activate the compliment cascade leading to intravascular red blood cell lysis, provoking an acute transfusion reaction. On 20th June, the patient had his orthopedic surgery and received Bombay blood arranged from think foundation of Mumbai, India.

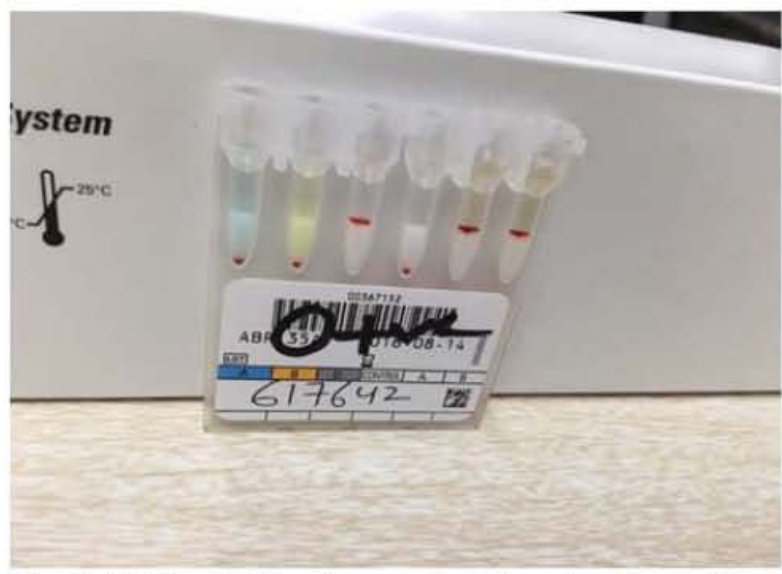

Fig. 1: Patient's blood grouping showing $O$ posittve without using $O$ cell in reverse grouping by column agglutination technology (gel card)

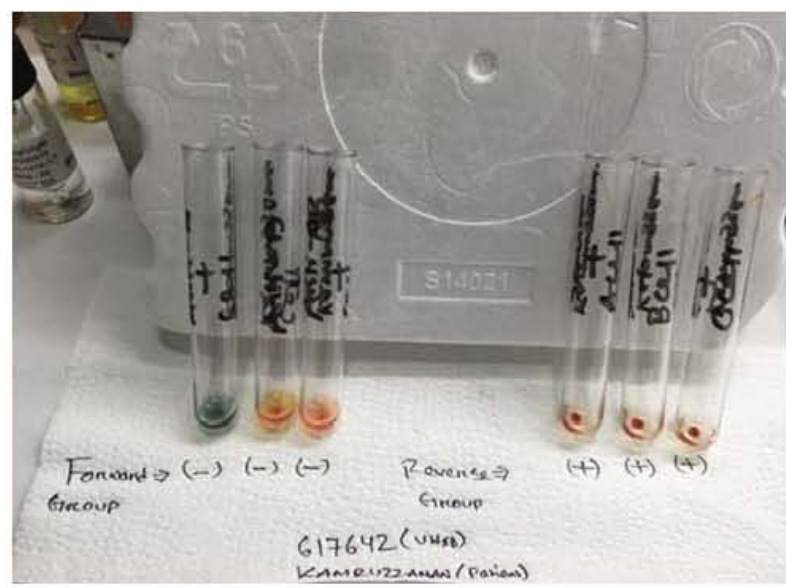

Fig. 2: Patient's blood grouping showing Oh phenotype (Bombay) using $\mathbf{O}$ cell in reverse grouping by Tube method 


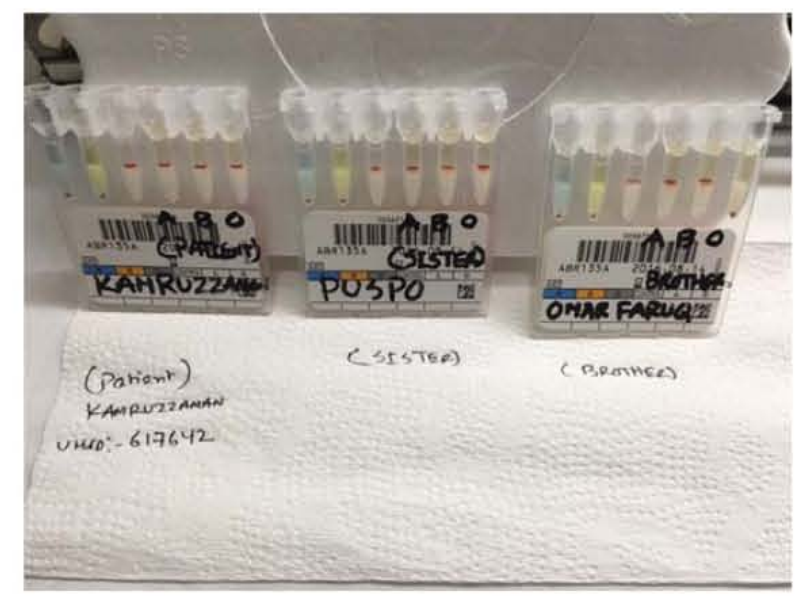

Fig 3: Comparing the patient (Oh phenotype) and her sister's (Oh phenotype) blood grouping showing strong reaction with $O$ cell in reverse grouping and his brother (OH phenotype) showing no reaction in reverse grouping by column agglutination technology (gel card)

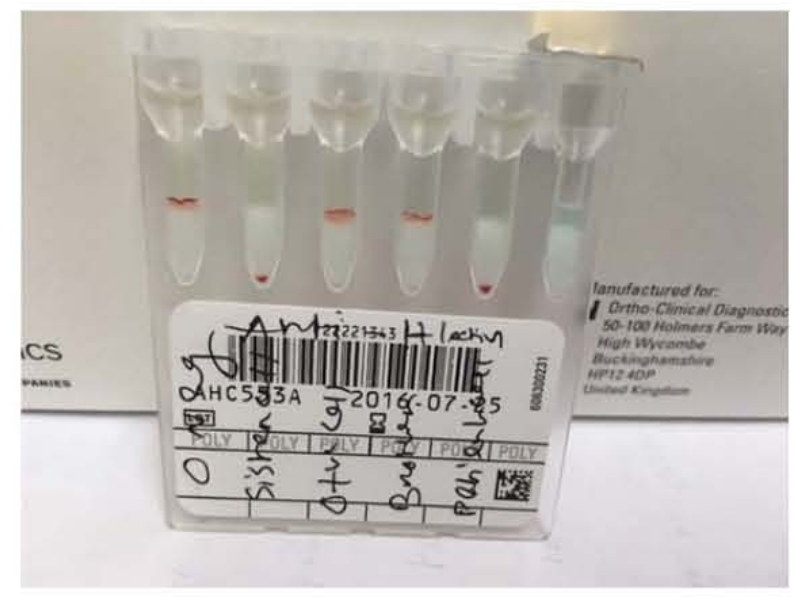

Fig. 4: Comparing the patient (Oh phenotype) and her sister's (Oh phenotype) Red cells showing no reaction with Anti $\mathrm{H}$ lectin and his brother $(\mathrm{OH}$ phenotype), $O$ positive and $O$ negative cells( $(\mathrm{OH})$ showing strong reaction with Anti $H$ lectin by column agglutination technology (gel card)

\section{Discussion}

In addition to $\mathrm{ABO}$ blood types, there are many other inherited blood group phenotypes. One of the most important type is rare Bombay phenotype, first reported in Bombay, India. India having the highest number of people with

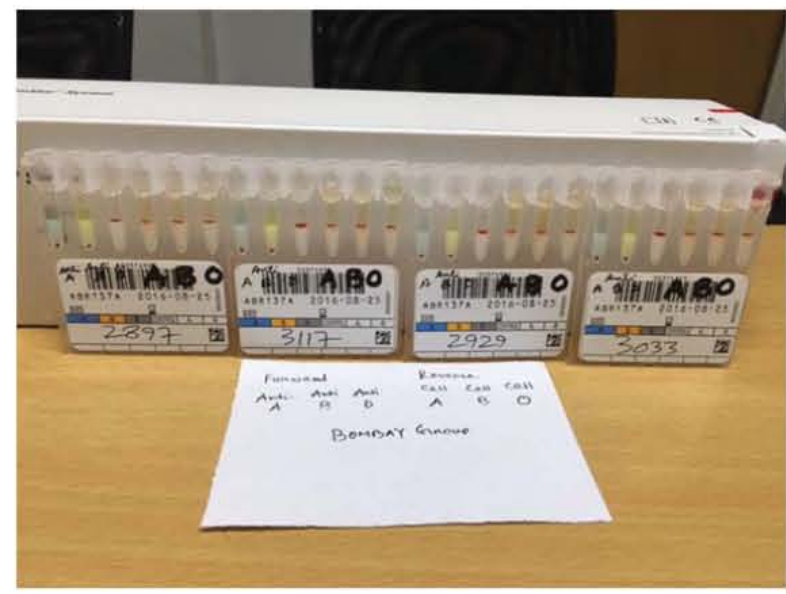

Fig. 5: Bombay blood group bags received from Think Foundation of Mumbai

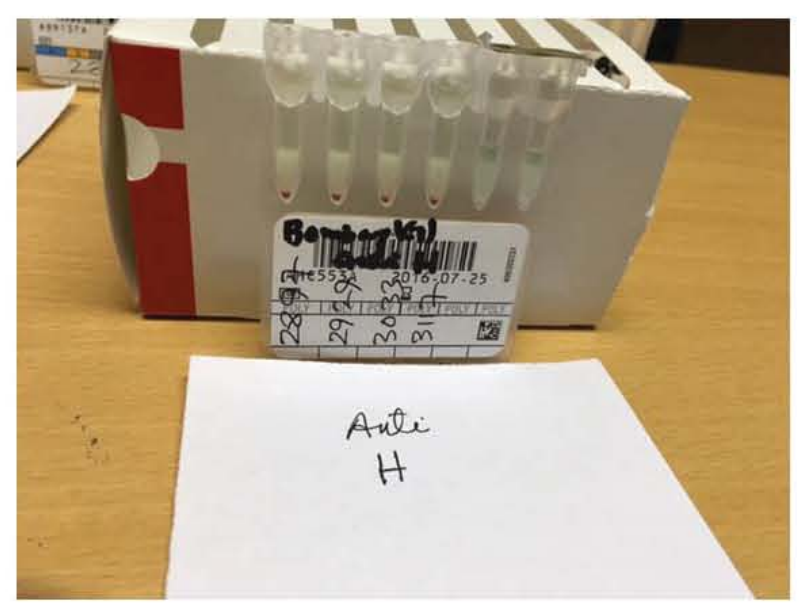

Fig. 6. Showing no reaction with Anti $H$ lectin of the blood bags (Bombay Group) received from think Foundation of Mumbai.

Bombay blood group with a probability of finding person with Bombay blood type is 1: $10,000,10$ lacks $H$ antigen and, consequently $A$ and $B$ antigen. Other variant with weak $H$ expression on RBCs is called Para-Bombay phenotype. ${ }^{4}$ 
Blood group system is a group of antigens encoded by alleles at a single gene locus or at gene loci so closely linked is very rare. ${ }^{10}$ The expression of A and B antigen is determined by $\mathrm{H}$ and Se gene, both of which give rise to glycosyltransferases that add L-fucose to a precursor substance to produce $\mathrm{H}$ antigen on red cells, ${ }^{10} \mathrm{H}$ antigen is synthesized by H gene (FUT1) and (FUT2) which is located on chromosome 19.5 Therefore, $\mathrm{H}$ antigen is present in all human erythrocytes except those in rare individuals of oh-(Bombay) phenotype. Oh Bombay phenotype individual is homozygous recessive (hh) genotype of FUT1 and hence cannot form the $\mathrm{H}$ precursor of the A and B antigen whereas in $\mathrm{ABO}$ blood group, the individuals carry the homozygous dominant $(\mathrm{HH})$ or heterozygous (Hh) genotype, and form $\mathrm{H}$ precursor of $\mathrm{A}$ and $\mathrm{B}$ blood group. ${ }^{10}$ Bombay phenotype individuals red cells and secretions lack $H$ enzymes and $H, A$ and $B$ antigens and their plasma contains potent wide thermal anti-H and anti-A, anti-B and antiAB. ${ }^{6}$

During cell grouping or forward grouping Bombay blood group may be categorized as $\mathrm{O}$ group. When cross matching with other $\mathrm{O}$ blood group, it would show incompatibility. Therefore, reverse grouping and anti $\mathrm{H}$ lectin has to be done to detect the Bombay blood group. These basic tests can prevent a patient from acute transfusion reaction. For our patient The $\mathrm{ABH}$ phenotyping was carried out by applying the standard forward and reverse grouping using $\mathrm{O}$ control cells in reverse grouping by tube techniques and also by column agglutination technology (gel card). The Bombay phenotype detected was further confirmed by certain specialized tests like titration of naturally occurring antibodies at different temperatures, cross matching with Bombay and non-Bombay $\mathrm{O}$ positive blood and no agglutination with $\mathrm{H}$ Lectin having Anti $\mathrm{H}$ like activity. Bombay phenotype (hh) individual has to be transfused only with RBCs that also lacks the $H$, $A$, and $B$ antigens i.e. they can either receive autologous donation or blood from an individual of Bombay phenotype only; no other blood will match in case of an emergency blood transfusion. Besides the Bombay blood transfusion, there is no other ill effect of being $\mathrm{H}$ deficient. Finding an $\mathrm{O}$ Bombay donor may be the tough part, but with the help of the rare donor registry in internet it would be very easy to find $O$ Bombay donor. Every blood bank should maintain a rare donor's hard and soft copy register.

\section{Conclusion}

Cross matching has the leading role in transfusion medicine. Cross matching is the only and most important weapon to diagnose any problem associated with blood transfusion. Blood grouping and antibody screening also has a very important role in spin or computer crosshatching.

Rare Bombay phenotype can be easily mistaken as $\mathrm{O}$ phenotype. So proper forward and reverse grouping plays a vital role in diagnosis of Bombay blood group. Reaction with $\mathrm{O}$ cell in reverse grouping gives a clue to the presence of anti $\mathrm{H}$ in patient's serum and no agglutination of the patient's cell with anti $\mathrm{H}$ lectin shows the absence of $\mathrm{H}$ antigen and thus confirms the diagnosis of Bombay phenotype. 
Oh Bombay patient can be transfused with Bombay group or autologous transfusion if the donation criteria are fulfilled. As the Bombay group is very rare in Bangladesh, blood bank needs to maintain the records of blood group and their contacts in rare donor register for their future transfusion and mutual help of other Bombay blood group individuals.

Bombay phenotype is mostly confined to South-East Asian countries. But Bangladesh has no specific statistics regarding this. First case was reported in 1990 and a few other cases according to internet. In this study, we report a case with the rare Bombay blood group that was giving the result as the $O$ blood group but was giving a strong incompatibility after cross matching with $\mathrm{O}$ blood group sample.

This highlights the both forward and reverse grouping including $\mathrm{O}$ control cell is important for safe blood transfusion, if not followed may lead to people with Bombay blood group not being detected and categorized as $O$ group. Therefore, reverse blood grouping along with $\mathrm{O}$ control cells in reverse blood typing is necessary to detect the Bombay phenotype and proper standard cross matching also plays a vital role in transfusion safety. Antibody screening also decreases the risk of hemolytic transfusion reaction.

\section{References}

1. The Hindu science- health science and technologyBombay blood.

2. Dean L Bethesda. The Hh Blood Group. Blood Groups And Red Cells Antigens. National Center for Biotechnology Information (US), 2005

3. Rahman $M$, Abdullah $A Z$, Hussain $M$, Haque $K M$, Hossain MM. A Bangladeshi family with three sisters 'Bombay' or Oh phenotype. Bangladesh Med Res Counc Bull, 1990 Dec; $16(2): 75-85$.

4. AABB Technical manual- 15 th edition. P-303-304.

5. Shahshahani HJ, Vahidfar MR and Khodaie SA. Transfusion reaction in a case with the rare Bombay blood group. Asian J Transfus Sci, 2013 Jan-Jun; 7(1): 86-7.

6. Chowdhury FS, Siddiqui MAE, Rahman KGM, Nasreen Z, Begum HA, Begum HA. A rare and clinically Important blood group - Bombay Blood Group. Bangladesh Journal of Medicine, 2011; 22 (1):21-3

7. Balgir RS. Detection of a Rare Blood Group "Bombay (Oh) Phenotype" among the Kutia Kundh Primitive Tribe of Orissa, India. Int J Hum Genet, 2005; 5(3): 193-198

8. Banu T, Ali SM. Rarest of rare Bombay blood group in Bangladesh: A case report. Journal of Bangladesh Society of Anesthesiologists, 2010; 23(1): 34-36

Balgir RS. Identification of a rare blood group, "Bombay $(\mathrm{Oh})$ phenotype," in Bhuyan tribe of Northwestern Orissa, India. Indian J Hum Genet. 2007 Sep-Dec; 13(3): 109-13

9. Sudha M, Govindarajan R and Parijatham BO. Bombay blood group - Case report. Medicine and Medical Sciences, March 2015; 1(1), 005-006

10. Balasubramanian D. Bombay Blood: how the rare blood type was discovered. The Hindu Sci-Tech. Health science, 2015 